Fighting for Indigenous Lands in Modern Brazil.

The reframing of cultures and identities

\title{
Tapeba:
}

\section{a synthesis of historical ethnography of ethnic territory and subjects}

\author{
Henyo T. Barretto Filho' \\ 'Universidade de Brasília, Departamento de Antropologia, Brasília/DF, Brasil
}

\begin{abstract}
This article summarizes ingredients from previous writings to undertake an ethnography of the process of constitution of the Tabeba ethnic territory, in Caucaia, in the Greater Fortaleza Metropolitan Region, until its recent recognition as an Indigenous Land by the Brazilian government. Considering my ethnographic experience and the various forms of engagement that I have had since the mid-1980s, I describe and analyze the constitution of the Tapebas as a collective political subject and the formalization of their territory. The paper addresses the various ways through which this occurred and highlights the factors that enabled it in various scales. I consider the different regimes to which this people was subjected, their process of ethnic individuation, and their path from stigmatization to their recognition as subjects with rights, by linking with a network of actors. I also highlight the main dimensions and situations that led to this.
\end{abstract}

Keywords: Tapeba; Ceará; indigenous land; territorialization; ethnogenesis; indigenous rights. 


\section{Tapeba:}

\section{síntese de etnografia histórica de um}

\section{território e sujeitos étnicos}

\section{Resumo}

O artigo sintetiza ingredientes de trabalhos anteriores com o objetivo de etnografar o processo de constituição do território étnico Tabeba, em Caucaia, Zona de Metropolitana de Fortaleza, até o seu recente reconhecimento como Terra Indígena (TI) pelo governo brasileiro. Considerando a minha experiência etnográfica e a multiplicidade de formas de atuação que tive desde meados dos anos 1980, descrevo e analiso o processo de constituição dos Tapebas como sujeito político coletivo e do seu território, abordando os diversos modos por meio dos quais isso ocorreu e apontando os fatores que concorreram para isso em diversas escalas. Abordo os distintos regimes a que esse povo foi submetido, o seu processo de individuação étnica, o caminho da superação do estigma ao reconhecimento como sujeitos de direitos, por meio da articulação com um emaranhado de atores. Também destaco as principais dimensões e situações que levaram a isso.

Palavras-chave: Tapeba; Ceará; terra indígena; territorialização; etnogênese; direitos indígenas. 


\title{
Tapeba:
}

\section{a synthesis of historical ethnography of ethnic territory and subjects}

\author{
Henyo T. Barretto Filho
}

\section{Introduction: objective and method'}

This article rearticulates and synthesizes ingredients from previous academic, technical-administrative and public awareness raising projects (Barretto Fo 1993a, 1993b, 1999, 2000, 2005, 2013 and 2017). My purpose is to conduct an ethnography of the constitution of the Tabeba ethnic territory in Caucaia, in the Fortaleza Metropolitan region, until its recent recognition as an Indigenous Land by the Brazilian Ministry of Justice, with 5,294 hectares (Portaria \# 734/MJ, de 31/08/2017). In the past, I wrote an ethnography and some articles about the Tapeba people and their land; coordinated two technical groups (GTs) formed to identify and delimit their indigenous land at two different times; ${ }^{2}$ and have accompanied from a distance both their political struggle for recognition and land, as well as the consequences of the demarcation procedure. ${ }^{3}$ am, therefore, in a relatively unique position to present this synthesis. It is by considering my ethnographic experience and the multiple forms of activity that I have undertaken since the mid 1980's, that I wish to describe and analyze the process of constitution of the Tapeba people as a collective subject and the formation of their territory. I address the various ways by which these processes took place and indicate some of the factors that have contributed to them.

In the subsequent sections, I address the effects that the various colonial regimes for the administration of indigenous peoples and the corresponding legislation for ordering land ownership have had in the configuration of the peoples and the region in which the municipality of Caucaia is now found. I will indicate how the Tapeba people can be understood as the result of a long historic process of ethnic interrelationship and individuation of segments of, at least, four distinct original indigenous peoples, who came together there, and were living under these regimes and laws. We observe the emergence of the Tapeba people in the public scene as a subaltern and strongly stigmatized ethnic group. We also accompany their

\footnotetext{
The original fieldwork was conducted in research for a master's degree in different periods in the second half of the 1980s. It was financed in each moment by the following institutions, to which I am grateful: Equipe de Assessoria às Comunidades Rurais da Arquidiocese de Fortaleza; Projeto Estudo sobre Terras Indígenas no Brasil; Programa de Pós-Graduação em Antropologia Social do Museu Nacional, through the "Bolsa de Auxílio à Pesquisa"; and the Programa de Dotações para Pesquisa FORD/ANPOCS of 1989. These were combined with support from CNPq and CAPES, which provided me master's grants from 1988 to 1990 . The ethnography presented here incorporates data produced in other contexts of ethnographic discovery: my coordination of two technical groups for the identification of the Tapeba Indigenous Land (IT) (see footnote 2). This article benefited from critical comments made by the editor of the dossier and by two anonymous reviewers, to whom I am grateful, for they considerably contributed to improve the text and the argument. Any errors that may have remained, however, are entirely my own responsibility.

2 I coordinated the technical groups for identification and delimitation of the Tapeba Indigenous Land established by Portarias of the President of the National Indian Foundation, Funai \#1.185 of 11/11/2002, \#097 of 12/02/2003, \#1226 of 01/09/2010 and \#1.847 of 02/11/2010. These were two different identification studies, conducted in two different periods and published respectively in 2006 and 2015 (see Barretto Fo 2005 and 2013). I conducted the first as a consultant to UNESCO hired through a shortened selection process established by Edital \#2002/01 to accomplish the elements of Contract \#14 (Identification and Delimitation of the Tapeba Indigenous Land). When conducting the second study I received a daily stipend as a collaborator of the National Indian Foundation.

3 A form of monitoring the effects of our technical production, which can be considered one of the possible consequences of "ethnography as sharing", which marks contemporary anthropology with indigenous peoples in Brazil (Pacheco de Oliveira 2013). Certainly, for this reason, in October 2015, at a formal session of the Ceará state Legislative Assembly, I and nine other people received a plaque to honor the important support and work dedicated to the Tapeba people over 30 years of activity of the Association of the Communities of the Tabepa Indians of Caucaia - Associação das Comunidades dos Índios Tapebas de Caucaia (ACITA).
} 
path to overcoming this prejudice and towards their recognition as subjects with rights, by means of their networking with a variety of actors (segments of the local population, the church, missionaries, unions, public agencies, academics, civil society organizations and social movements).

In this process, I will highlight the main social, political, legal and administrative dimensions that have led to recognition of the territorial rights of the Tapeba people and their strategies for retaking and occupying their territory. I do this by analyzing the connections of these strategies with the way they live their ancestry and traditions, and with the configuration of the interethnic relations - considering the local forms of intervention of various agencies, including those of the state. I pay attention to the formation of indigenous associations and to the political mobilizations led by the indigenous peoples, and I seek to describe and analyze projects the Tapebas have developed for their future. These projects appear to be based on an effort to strengthen their identity through education and citizenship (by participating in party politics) and to share horizons with other peoples and communities of Ceará.

Before moving on, two observations are necessary, one methodological and another theoretical.

As I have mentioned, this article connects data produced by different methods: empiric investigation based on direct and participant observation with the Tapeba people, in which the oral traditions are an important source; and document research of the historiography available about the region under consideration, which revealed a variety of records produced in different contexts and spheres. I led this research for both strictly academic purposes and during the procedure for demarcation of the Tapeba Indigenous Land. It is important to note that the official, accessible historiography and documentation express the cultural concepts and future projects of dominant sectors of society, which as a rule have been responsible for the subordination - if not the annihilation - of the indigenous peoples and for the expropriation of their territories and resources that support their socio-cultural reproduction. It can be expected, therefore, that the ethnographic and historical knowledge about the indigenous peoples of Ceará produced in the colonial and imperial periods and in a good part of the Republican period, are scarce and confused - particularly those found in recognized and authorized records, which often present ambiguous data, conflicting information and gaps. More than categorical sources about the truth of the indigenous presence in Ceará, the historic documents and studies referred to here are considered first as an expression of the different regimes of visibility of the indigenous peoples over time.

I deploy with a certain freedom - but also with some grounding - the notion of historical ethnography to characterize this synthesis. I have in mind a broad set of contributions that consider the places of ethnography and history in anthropology as mutually complementary modes for reflecting about oneself and the other. For Comaroff and Comaroff (2010), for example, ethnography and history are forms of connecting fragments to which we have access in empiric research to broader historically and culturally determined contexts, which confers meaning to them. Sahlins (1993), in turn, by commenting on various works that sought to synthesize the experience of field work in a community with the study of their archival past - as I highlighted above for the methodological dimension of this article - identifies a different type of ethnographic prose. It is a type of ethnohistory, a specific anthropological project and genre that he calls historical ethnography. According to Sahlins, works like that of the Comaroff couple in South Africa, and others, raised in a conscientious way the argument that ethnographies that consider time and transformation provide a distinct form of knowing the anthropological subject. For Sahlins, the purpose of a historical ethnography is not to provide lessons of cultural continuity, but to synthesize structure and variation, as a significant social process that leads to a specific cultural order. In Brazil, for some time now Pacheco de Oliveira has been undertaking a historical anthropology to consider indigenous societies and cultures in Brazil. For Pacheco de Oliveira, an understanding of these societies and cultures "cannot be conducted without a critical reflection and retrieval of their historical dimension" - understood 
as the "space-time axes" through which the indigenous act as "full historic subjects" (Pacheco de Oliveira 1999a: 8). These are the inspirations that guide this exercise.

\section{Following some leads: toponyms, nicknames and ethnonyms}

Tapeba is originally a toponym. It is the name of a lake and of a periodic stream that in the winter carries waters from the Coité and Juá Mountains, and the Porcos lake, and flows into the Juá River, close to the Barra Nova lake. Both, the lake and the stream are located in a rural portion of the municipality of Caucaia, and indigenous families live close by, in a region where they form the majority of the population. In 1721, the toponym Tapeba lake was registered - as well as the Capuan Lake - in a land concession known in Portuguese as "data and sesmaria" (Souza 1933: 204, vol. 6). ${ }^{4}$ Tapeba is a word in the Tupi language, ${ }^{5}$ according to various authors, and is a phonetic variation of itapeva (from tá|itá, which means "stone" and peva, which means "plane" or "flat"), and thus signifies "plane stone", "flat stone" or "polished stone". Caucaia, the name of the municipality, is also of Tupi origin, although there is controversy about its meaning.

This toponym helps us to understand the use of the terms "Caucaia Indians", "Caucaios" or "Indians of the general language known as Caucaios" that are found in many historic documents to refer to the Indians of the village of the same name (see the next section; cf. Machado 1902: 198). The same logic explains the use of the name and or nickname of an ancestor to single out the group, by reference to this common ancestor. Menezes, for example, refers to the "Indians of the Algodão nation", "founders [of] Caucaya" (Menezes 1871: 262). This seems to be an allusion to "chief Tapuyo Amanay or Algodão" with whom the Jesuits Francisco Pinto and Luís Figueira, in a pioneering phase of colonization, had become friends during their passage through the region of Mucuripe. With Algodão's help they had founded the villages of Caucaia, Parangaba, Paupina and Pitaguary, where they had gathered the Potiguaras they met who were on the expedition of Pero Coelho (Brigido 1879: 12).

More recently, we have "Pernas-de-Pau" (wooden legs) and "Tapebanos", which serve as ethnonyms in the local social landscape. The first refers to the nickname of an ancestor - José "Zé Zabel" Alves dos Reis - who lived at a location called Paumirim, to which a segment of the Tapebas - the "Zabel" family - commonly refer when tracing their genealogy (cf. Almeida, G. 1988). The second functions as an adjectival phrase for "from Tapeba", "native of Tapeba", "child of Tapeba", "resident of Tapeba" or others, as if they were defining a "district ethnicity" (Ahmed 1984), in reference to the location of origin, residence and or birth.

Thus, it should not come as a surprise that the term Tapeba does not appear in colonial documents linked to a specific indigenous people. The colonizers referred to the Indians who lived in Caucaia by the name of a Potiguara chief ("the Algodão" nation), or by the name of the village itself ("Caucaio" Indians). The toponym Tapeba also appears to have been used to designate the inheritors of the indigenous peoples found there, and who, by a set of circumstances that will be described below, came to reside around the lake and stream of the same name.

It is important to note that the toponyms speak a living language and result from the process by which one language is imposed upon and dominates another, thus expressing a given knowledge about the territory. The persistence of these Tupi toponyms over time appears to express, on one hand, the dominant presence of the Potiguara people who resided in this region since the first half of the seventeenth century (see below), and on the other, the continuity of the indigenous presence in Caucaia. Social anthropology

\footnotetext{
4 "Data" and "sesmaria" are terms related to the regime for the concession of rights to landed property upon which the appropriation of land ownership in Brazil was based until its abolition in 1822. "Data" is the document that grants rights to the land itself, known as the "sesmaria".

5 As nearly all local toponyms: Capuan, Capoeira, Jenipabu, Icaraí, Iparana, Jandaiguaba, Pabussu, Paumirim, Tabapuá, etc.
} 
recognizes that geographic references are often central to the constitution of ethnic groups, given that they are appropriated to report common origins and ancestries, marking the belonging to a group that regards a given territory as ancestral (Pacheco de Oliveira 1999b) ${ }^{6}$.

\section{The colonial machinery for crushing and producing peoples: a historiographical synthesis}

The available sources reveal that the history of the region where the Tapeba people now live in the municipality of Caucaia is intertwined with the history of conquest and peopling by Europeans - the French, Dutch and Portuguese - of the region that is now the state of Ceará. This history is closely related to the movement of the aboriginal peoples that lived there before the arrival of the first colonizers (Almeida 1986; Cordeiro 1989; Gomes 1985a, 1985b; Porto Alegre 1992a). According to evidence gathered in various studies, what is now the municipality of Caucaia originated in what was the village of Nossa Senhora dos Prazeres. ${ }^{7}$

There are various hints in the historiography about the pre-colonial indigenous presence in what today is the Ceará coast, in particular the origin of the indigenous contingent initially found in the village of Caucaia: the Potiguaras that were already found there trading with the French at the time of the arrival of the expedition of Pero Coelho, in 1603; the Potiguaras that came with his army; the Potiguaras and Tabajaras that Father Luís Figueira compelled to accompany him on his return from the first mission to the Ibiapaba mountain range; and or all of these options simultaneously. The Mapa Etno-Histórico de Curt Nimuendaju [Curt Nimuendaju's Ethno-Historic Map], in turn, registers the presence of Potiguaras in the seventeenth and eighteenth century on the coast close to Fortaleza and to its northeast.

There are also different accounts of the number and location of the villages established on Cearás coast by the Jesuits, in that which Serafim Leite considers the pioneering phase of the missionary activity of this religious order in the territory that now corresponds to Ceará - a phase that was marked by "transitory exploration and catechism". The Jesuit missionary activity in Ceará encompassed a period of nearly a century and a half (apud Gomes 1985a: 4-5). Despite a dissonant narrative about the first stable colonial settlements in this region, the sources appear to agree that the settlements already existed in 1694, four of which (Caucaia, Parangaba, Paupina and Parnamirim) were of Tupi Indians and two others of Jaguaribaras - "all [...] intensely inhabited, as can be seen in the letter of Morais Navarro, dated July 1694, and written in Bahia" (Studart Fo 1963: 175-176; emphasis mine).

The period of Dutch dominion inevitably influenced the indigenous and non-indigenous demographic dynamic in what is now Brazil's Northeast, promoting movements of various kinds. The sources show that the Indians were active political subjects, capable of making choices and defining the alliances that seemed preferential and beneficial to them, suggesting an admirable capacity to adapt to new and adverse circumstances imposed by the dispute between the colonial powers. This was demonstrated in 1644, when the Potiguaras who had come to work in the salt works ${ }^{8}$ of the West Indies Company, revolted once again

\footnotetext{
6 In this way, the Tapeba are similar to countless other peoples considered by the vast ethnological literature, which we can broadly cite here: the relationship between the Kambiwá and Pipipã with the Serra Negra (Barbosa 2001); the Atikum and the Serra do Umã (Grünewald 2004); the Pataxó and Monte Pascoal (Carvalho 2009); the Xukuru and the Serra do Ororubá (Fialho 1998); the peoples of the lower Oiapoque and the Curipi, Urucauá and Uaçá rivers (Tassinari 1999).

7 Almeida distinguishes aldeia [village], "in an allusion to the traditional indigenous dwellings", from aldeamento [a constructed settlement], "which refers specifically to constructions made by the colonizers to settle the Indians", opting for the second term (1986: 7). We maintain "aldeia" [village] as it appears in the available historiography and in the reports from that time, because we understand it as a historic category that denotes a certain mode/model of land appropriation, as made explicit by Faulhaber: "the indigenous aldeia constitutes a historically rooted category and appears in the discourse of the first travelers, associated to the strategic formation of population groupings, and is linked to the missionary practice of enslavement and Baptism, in which the Tuxauas and indigenous heads themselves participated" (1989: 2).

8 The reference to the salt works in this region is important. The activity was probably favored by the estuaries of the Ceará and Cocó rivers, and the indigenous work at them. This is because there is data, for the twentieth century, of Tapeba Indians working at salt works on the Santa Rita farm, which
} 
against the same oppressive, cruel and dishonest treatment they received from the Portuguese, and the lack of payment of the promised salaries. They took the small Dutch fort and murdered everyone they found.

In 1654, when Portuguese rule was re-established by the definitive expulsion of the Dutch and delivery of the Captaincy of Ceará to the Portuguese, the Jesuits resumed the work of indoctrinating the Indians. This took place under the aegis of the Regiment of 09/04/1655, which established the independence of the missions in the sertão [as the semi-arid interior is known] in relation to the governing officials and to the local civil authorities (Beozzo 1983: 38). Since then, there has been a pendular movement typical of the legislation concerning the administration of indigenous peoples in colonial Brazil, which extended until the mid-nineteenth century: at one moment it would favor the religious orders, and at another the civil secular settlers and administrators and their demands for indigenous labor.

This process took place in parallel to the beginning of the sharing of the land effectively conquered by the Portuguese Crown by means of the land concessions, the datas and sesmarias. Struggling among each other for the lands, due to confusions in their distribution and boundary disputes, the settlers frequently used the Indians as their soldiers - requesting them from the village administrations, from the captains - and hundreds of Indians died. The development of husbandry in the interior, mainly in the Jaguaribe Valley, intensified the continuous struggle between settlers and Indians, who were hunted, killed, enslaved or expelled. The "fazendas de criar" [cattle farms], according to Cordeiro, were the characteristic form of the colonial enterprise in Ceará and one of the "structural supports of the colonizing model": a "mark of occupation and possession of land legalized by the sesmarias regime" (Cordeiro 1989: 35). The opposition was so strong, that the civil authority was required to turn to the Paulistas, who had troops experienced in suppressing indigenous resistance (cf. Cordeiro 1989).

In the first quarter of the eighteenth century, sesmarias came to be granted by the Portuguese Crown to the Potiguara villages on the Ceará coast. This probably took place as a retribution for the collaboration of this people in the suppression of the revolts, or even as a result of the expansion and consolidation of the temporal and spiritual administration of the villages under the direction of the religious missionaries. On 23 November 1700, a writ, that became law on July 4, 1703, granted to each mission "a square league of land to support Indians and respective missionaries with the declaration that each village must be composed of at least one hundred couples" (apud Dantas et al. 1992: 444). The Indians of Caucaia were contemplated by the data of sesmaria issued on March 31, 1723, which conceded to the indigenous leader of the Caucaia village and other officials and Indians, for their use and that of their heirs, an area of three leagues of land, one league wide, and half a league to each side, running along the spring known as Taboca (Datas 1925: 47).

We thus have, at the late seventeenth century and early eighteenth century, a situation in which the villages of the Tupi Indians on the Ceará coast had a territorial heritage upon which they based their activities and whose administration - in particular of the indigenous labor - was disputed among civil and religious authorities. To this was added the confusion and countless conflicting demands about the limits of the datas for sesmarias, which were widely issued by the Capitães-mores, the top officials. This is a period about which there is more frequent information about the villages and their composition.

The "settlement prospered" (IBGE, 1959: 151) when in August 1758 the Diretório Pombalino9 was applied to the state of Brazil. The villages of Ibiapaba (Vila Viçosa Real), Caucaia (Vila de Soure), Parangaba (Vila Nova de Arronches) and Paupina (Vila de Messejana) were raised to the status of vila [town]. The village of Caucaia, when it was raised to the category of Vila Nova de Soure, "was a Potiguara village, with Tremembé Indians on the outskirts, missioned by the Jesuits" (Braga 1967: 349).

encompassed a large area of the mangrove swamps at the estuary of the Ceará River.

9 The Diretório Pombalino determined a major shift in the administration of indigenous peoples and lands in colonial Brazil, which resulted in the secularization of this administration, the expulsion of the Jesuits, the change of settlement names to Portuguese and a series of other actions with far-reaching consequences. 
The information about the ethnic composition of the Indian vilas close to the coast and located around Fortaleza was invariably linked to the news about the abuses and atrocities committed by the Directors (the new local administrators). These Directors regularly complied with requests by the local population to supply Indians to do outdoor work and were responsible for regulating the distribution of the Indians among the residents. The Indians in Ceará suffered constantly from the abusive and violent regime of the civil directors of the vilas and from the policy at the time that allowed appropriation of Indian lands. Nevertheless, Vila de Soure, like others, is referred to as an "Indian vila", in both official documents and in reports produced by travelers, and legal and religious authorities, since its creation until the first quarter of the nineteenth century - as synthesized in Table 1 below.

Table 1 - Demographic Changes at Vila de Soure, according to various sources

\begin{tabular}{|c|c|c|}
\hline Year & Population & Sources and Observations \\
\hline 1759 & 600 Indians & Leite 1943 \\
\hline 1777 & $\begin{array}{l}\text { 1,388 inhab.: mostly "settled indigenous population". Soure was } \\
\text { an average size Indian vila. }\end{array}$ & Porto Alegre $1992 b$ \\
\hline 1808 & $\begin{array}{c}767 \text { hab.: } 546 \text { “Indians" (26o men and } 286 \text { women; } 71 \% \text { ), } 33 \\
\text { "mulattos", } 55 \text { “blacks" and } 33 \text { "whites" }\end{array}$ & Menezes 1871 \\
\hline 1811 & $\begin{array}{l}816 \text { hab. Soure was one of the smaller population centers of } \\
\text { Ceará. }\end{array}$ & $\begin{array}{c}\text { Menezes } 1871 \\
\text { IBGE } 1959\end{array}$ \\
\hline 1816 & 1,050 residents & Paulet 1898 \\
\hline 1821 & 1,200 residents - "All Indians" & Braga 1967 \\
\hline
\end{tabular}

It is probably during this period that the understanding was developed that the territorial patrimony of the Vila de Soure was the property of the Saint (Our Lady of Prazeres - the Virgin Mary) - an understanding that is expressed in the current territorial concepts of the Tapebas about the "square league" of the "Saint's land" (see below). An example of this is the deed for the donation of lands of 11/08/1816, by means of which Mr. Francisco Barroso de Souza and his wife donated an area to "Our Lady of Prazeres of this Regal Villa de Soure". The deed mentions the "lands of the vila" and "the Indian owners of this vila" within the boundaries of the donated area (Gomes 1985b: 13; Studart 1896: 499).

The voluminous official correspondence between government authorities at various levels is valuable because it reveals multiple dimensions of the life of the Vila de Soure's Indians. It refers to: slave and hired labor of indigenous men and women; distribution of this labor among private parties; chastisement and punishments for Indians who fled or refused to obey orders; economic activities that were promoted and given incentives, such as planting cotton, cassava and other food crops, and fishing and sale of crabs, oysters and mussels ${ }^{10}$ forced recruitment of indigenous contingents to fight against and in autonomist political movements; successive nominations of various officials, like capitães-mores and sargentos-mores (higher captains and higher sergeants) to oversee the Indians of Soure; relocation of indigenous populations among vilas of Indians, Soure included; statistical control of the indigenous population; and the imprisonment of Indians. The documents both confirm the expressive indigenous presence in Soure until the first third of the nineteenth century, and show how the Indians' lifestyle was shaped by the repressive and disciplinary mold of the colonial power.

Considered altogether, the references show that the Diretorio, in an authoritarian and violent manner, transferred and resettled indigenous populations among the vilas, mostly from the interior to those close to the coast and the capital. This practice probably sought to avoid the dispersal and reorganization

10 An economic activity that is maintained by the Tapeba until today in the Rio Ceará estuary. 
of the Indians in terms that threatened the availability of labor for the services of the colony, or that would stimulate the eruption of forms of resistance. Thus, considering the information registered by the colonizers' pens, everything leads to the conclusion that the indigenous contingent of the Vila de Soure had a diversified ethnic composition. There are indications that at least four indigenous peoples were joined there: the original Potiguara, the Tremembe from the surroundings, the Kariri and the transferred Jucá. According to oral witnesses, they were joined by free and or escaped enslaved blacks and those fleeing from the drought of the "three eights" (1888). Given the varied ethnic composition of the indigenous population of Aldeia de Caucaia/Vila de Soure, one can say that the Tapebas emerged from a historic process of ethnic individuation of these distinct sections, living under a violent regime of slavery and disciplinarization of their lives.

After the enactment of the 1845 Regulation and the promulgation of the "Land Law" (Law \# 601, of 09/18/1850), which sought to regulate land ownership in the country, official documentation about the Indians of Ceará became scarce and changed its tone. The provincial government came to emphasize issues involving the goods and territorial assets of the Indians. The lands of the Indians (aldeias [villages] and vilas [towns]) were included in the Plan of the Land Law and the Decree of 1854 as areas to be demarcated and regularized. In case the lands of the villages were no longer "occupied" by the Indians - according to government evaluation and criteria - it would consider them "national property". If they were occupied, however, the lands would remain in the possession and use by the Indians, even if the villages were extinct. This is why Ceará was "the first province to deny the existence of identifiable Indians in the villages and to want to appropriate their lands (10/21/1850)" (Cunha 1992: 145).

On Oct. 9, 1863, at the time of the installation of the Provincial Legislative Assembly, the then President of Ceará Province declared that there were no more Indians, either settled or in the wild, in the province of Ceará and that the territorial assets of the villages would be incorporated to the Treasury by imperial order. This declaration is ambiguous because it also: (i) proclaimed that 120 land possessions of Indians of the old sesmarias of Messejana and Maranguape were legitimated; (ii) referred to "possessions of some Indians" that were respected; and (iii) reported that they were "waiting for detailed information", requested at the time, concerning the possibility that there were survivors of the invasions, exterminations and diseases, who may have migrated to regions where they were allowed to remain. It became a common measure at that time to declare the inexistence of Indians in areas of economic interest, characterizing them as terras devolutas (supposedly unoccupied and unused public land), under the terms of the Land Law of 1850. Among the most common forms of usurpation allowed since the 1845 Regulation were: movement and concentration of Indigenous groups; and the settlement of "wild hoards" in their original territories - with the ensuing reduction of their occupation - that authorities tried to declare to be village lands. By doing so, they allowed the rental and leasing of lands that were supposedly reserved, but which in fact were immemorial lands, allowing tenants and settlers to pressure the government to obtain Indians' lands.

Evidence thus suggest that the villages were extinct and their lands liquidated, without the formal donation of their lands to the Indians, as established by the series of regulations. The same registers which are ambivalent and biased - indicate the possibility that some indigenous peoples had remained in possession of parcels of their lands, that is: that some possessions were respected, despite the fact that the lands as a whole had been incorporated to the provincial treasury and then leased by the town governments. 


\section{The "Saint's Land", marginalization and stigma: oral traditions and witnesses}

The data from the historiography referred to previously indicate an unstable situation, in the nineteenth century, in terms of the destination of the lands of the extinct indigenous villages. The situation of the Tapebas can thus be characterized as the product of two different historical paths, generally found in regions of early colonization, such as the Brazilian Northeast: (1) the disaggregation of territorial domains belonging to the church, where forms of common use had come to prevail, for which reason the "Saint" (Our Lady of Prazeres) appears as the owner; and (2) the loss of possession of any titled domains that may have been formally issued to indigenous leaders and their descendants as a donation, or in retribution for services provided to the State.The notion of the "Saint's land" appears repeatedly in references to the past recounted by the Tapebas, in personal statements and oral testimonies produced in different field situations. It maintains a strong coherence with the historic registers about the Aldeia/ Vila and with the territorial concessions made to the indigenous leaders and their descendents, and with what happened to this territorial patrimony. Oral narratives also indicate that since the beginning of the twentieth century the ethnic ascriptions Tapeba, Tapebano and Perna-de-Pau were used to refer to segments of the population to which indigenous origin was recognized and to a peculiar lifestyle and forms of behavior.

Oral testimonies, field observations and some official technical documents provide us an approximate idea of what might have been the square league of land of the former Indians' Aldeia de Caucaia/Vila de Soure: it would form a quadrilateral, its limits encircling what is now the urban perimeter of the central region of Caucaia. The referents of the testimonies produced during fieldwork also agree with some of the landmarks of the limits of the "square league of land in the Soure township" described in the document "Terra do Patrimônio da Câmara da Extinta Villa de Soure" [Land of the Patrimony of the Town Hall of the Extinct Vila de Soure]. There is explicit mention of the "league of land of the Virgin Mary", with clear references to the landmarks: Sargento-Mór, Rio Ceará, the Tapeba stream and the "bar of the Ceará River". The Tapebas are not mistaken, when they say that "all of Caucaia is indigenous".

This is somehow expressed in the use that both the Tapebas and the regional residents currently make of the toponym Tapeba. It is more frequently used to refer to an inclusive, generic area with vaguely defined limits, embracing the lake and the stream of the same name, incorporating the Porcos lake to the south, the Santa Terezinha quarry, Cutia and the Bestas Lake to the west, the settlement of Capuan to the north and the Ceará River to the east. These sites are often all encompassed by the toponym Tapeba, giving the observer the idea that, as they used to say: "It is all one place. It is all one land".

Whatever had been the precise territorial patrimony of the Saint, it was handed on to the administration of the city council, which in turn, came to grant leases to parcels of land. The statements produced in different fieldwork periods refer to this phenomenon, even if generically, by indicating that the league of land mentioned was being progressively occupied by people of greater wealth. These statements show both the consistency of the oral tradition about the right of the Tapebas to the "Saint's land", and reveal that various forms of land appropriation developed over time. These modalities are the fruit of the different historical solutions that sectors of the Tapebas engendered in relation to the disaggregation, whether of the patrimony "of the saint", or of any titled lands. They include:

- The condition of "residents" of parcels of lands belonging to third parties, with a relative consent to use the land and its natural resources, based either on informal agreements, or on fictitious kinship ties (compaternity), or on the payment for the land with a portion of agricultural production;

- The condition of free and individual control of land and of basic resources exercised by one or another domestic group - which was found until recently in some cases; and 
- Systems of common use in some specific situations, in which various domestic groups, which compose a given social unit - as is the case of some unrestricted bilateral descent groups - exercise the control of the basic resources of a given area, according to specific rules consensually agreed to in the meanders of social relations established among them. ${ }^{11}$

The Tapebas were not able to fully guarantee the domain over their lands, generation after generation, due to mechanisms of unequal exchange to which they were continuously submitted. The history of the current Tapeba villages is related to relatively recent changes in the forms of land appropriation previously found in the Tapeba and Paumirim - which, as far as their genealogical memory extends, are the locations they recognize as their traditional dwellings.

Since 1910, with the beginning of the construction of the Baturite railway line, one of the branches of the Cearense Railway System, and later with federal highway BR-222, the appropriation of these areas by the Indians took a distinct character with the expansion of access routes to the region. Since the second third of the twentieth century, the rising real estate values in the metropolitan zones near the state capital caused the expulsion and dispersion of a large number of indigenous families, who came to form the currently existing villages. The families from Tapeba and Paumirim were led to occupy marginal areas and federal government lands: the mangrove swamps and the margins of the Ceará River, which are federal lands in tidal areas (where, since the colonial period, Indians fished and sold crustaceans); the strips of the rights of way of the highways and railways opened at that time; and the peri-urban zone of the city, having witnessed the neighborhoods of the urban perimeter encapsulate their old settlements. This partly elucidates their distribution around the urban perimeter of Caucaia.

It was in this situation that the Tapebas were rediscovered by journalists and academics in the second half of the 1960s. José Rangel Cavalcante and Rodolfo Espíndola, who were respectively correspondents for the newspapers Jornal do Brasil [from Rio de Janeiro] and O Estado de São Paulo, wrote long articles about the Tapeba. The piece, "Indígena no Ceará não é Cidadão" [Indigenous in Cerá is not a Citizen], by Cavalcante, was published on April 7, 1968 in the Jornal do Brasil; and "O triste fim dos índios cearenses" [The Sad End of the Cearense Indians], by Espindola, was published on July 6, 1969 in the O Estado de São Paulo. Evidence of the repercussion of these articles among the local intellectual community were the transcription of Cavalcante's complete text in the Revista do Instituto do Ceará in 1968 and an op-ed entitled “Índios Cearenses", in the edition of July 12, 1969 of the Correio do Ceará, about Espíndola's article. Espíndola wrote again about the Tapebas in the mid-197os and early 1980s: on August 1, 1976, the $O$ Povo newspaper published a special section by Espindola entitled "Tapeba: o índio que esqueceu as origens" [Tapeba: the Indian who forgot his origins] (p. 31); and on May 2, 1982, the O Estado de São Paulo once again published an article entitled "Os últimos Tapebas na miséria" [The last Tapeba in poverty].

The tone of these articles - which highlighted misery, cultural disintegration, and imminent demise reflects the stigma that weighed on the Tapeba and their ways of life when I met them in 1986, still in the situation of a subaltern and vulnerable group. This stigma, which until today hangs over the Tapeba, results from the progressive cultural and territorial marginalization mentioned. It appears to have functioned for a long time as a social and ideological barrier to interaction with the regional population, limiting the possibilities of relationships outside the "family" - in the sense that they attribute to this term - and intensifying the connectivity of the network of relatives, neighbors and work partners.

For decades, expectations of disreputable behavior shaped interactions of the Tapebas with nonIndians, contributing to the consolidation of the ethnic adscription and to their circumscription as a

11 The Tapebas are trying to reconstitute these systems in a proactive and gradual manner through "retomadas" [retakings] (see below). 
distinct group of people based on references to their manners. The term Tapeba continues to spark a reference to a certain ethos and disreputable standards of behavior, such as: excess drinking of cachaça (if not alcoholism); eating spoiled red meat or carrion (a practice that, like the previous one, they recognize that some ancestors practiced); a lack of hygiene and basic care (filthiness); resort to incestuous relations (the pejorative meaning of the term "mixture", when used by non-Indians); robbing and conducting illicit productive activities, or those not considered as work in the conventional sense of the term (usually extractive activities). The Tapeba ethnic ascription, therefore, incorporates symbols of stigma and constitutes, on its own, a symbol of stigma - or "discrimination", as a number of them said - operating even as a disparagement in certain circumstances. This is why testimonies and statements refer to the "revolt" and violent reaction - the "fighting" - that took place when Tapeba was used to address or call with explicit intentions to "esculhambar", "se desfazer" and "rebaixar" (humiliate, denigrate and degrade) the Indians.

Add to that the ubiquitous use of the term "family" by the Indians in relation to the Tapeba adscription, forming expressions such as "Tapeba family" or "family of/from Tapeba", which refers to the intimate social ties of this group and to the affective and traditional subjective feeling of constituting a whole. The territorial reference is umbilically linked to the recognition of the descent of the families that lived in the Tapeba - understood in the broad sense (see above) - and in Paumirim. The possibility - and even the deliberate effort - of one person or domestic group to acknowledge and have acknowledged their origin with reference to areas considered to be the dwelling places of the Tapeba in the recent past, constitutes a referent of the ethnic adscription. As we see, there is a close tie between the ethnonym and the toponym, establishing an adscription based on the mutual recognition of common origin as a basic fact, which is tied to a series of discrediting attributes. The Tapeba also often say that the families "Zabel" (Alves dos Reis, Alves Teixeira), "Coco" (Alves de Matos, Teixeira de Matos), Jacinto, Jerônimo do Nascimento (“Grande”), "Milunga", "Carnaúba”, “Guimarães," and Paiva ("Macaco"), are Tapebas, or of/from the Tapeba. These "families" from the "Tapeba family" comprise unrestricted groups of bilateral descent by means of which it is possible to acknowledge the genealogy of a person as Tapeba.

\section{From stigma to recognition: Indians as subjects with territorial rights}

This process began to change in 1984, when the Equipe de Assessoria às Comunidades Rurais [Rural Communities Advisory Team] (EACR) of the Archdiocese of Fortaleza started working with the families living in risk areas (subject to flooding) along the mangrove swamps of the Ceará River - without knowing, at first, that they were working with sections of an indigenous people. The Archbishop at that time was Dom Aloisio Cardeal Lorscheider, who had previously been archbishop of Aparecida - the site of the basilica of Brazil's patron saint - and a former president of the National Conference of Brazilian Bishops (CNBB), which granted important symbolic weight to the action of the local social pastoral entities. The results of this work were many, which at times diverted into social assistance activities of a charitable nature. Some, however, are worth mentioning because of the long-lasting effects that they had on reversing the expectations and self-esteem of the Tapeba themselves.

Based on an initial incentive from the EACR, the Association of Communities of the the Ceara River (ACRC) was created in August 1985 as a private, not-for-profit civil society entity, based in the Rio Ceará community, at the location called Pontes, in the municipality of Caucaia. The Association of Communities had duplicated Board of Directors and Fiscal Board, with equal occupation of the same positions and functions by Tapebas and non-Indians. Its objective was to "unite and organize the affiliated communities, lead integrated programs aimed at physical and spiritual growth of its members, defend human rights, collaborate with public and private entities to defend the mangrove swamps, rivers and other natural 
assets for their ecological preservation and equilibrium, and collaborate with the Federação dos Indígenas Tapebas" [Tapeba Indians Federation] (by-laws of the association published in the Diário Oficial do Estado do Ceará on Aug. 27, 1985). It was initially formed by 14 "indigenous communities and nuclei": Vila Nova, Vila São José, Pista, Ilha, Ponte 1, Ponte 2, Capoeira 1, Capoeira 2, Lado do Daniel, Cigana, Trilho, Lagoa dos Tapebas, Barra Nova and Açude - and was soon joined by Mestre Antônio, Malícias, Itambé and Grilo.

At first, the Association's dynamics comprised meetings each Wednesday at Ponte 1, the association's central space, and each Sunday rotated to one of the 17 "communities". Sebastião André da Conceição, the Sebastião "Crente", who at the time was a sociocultural promoter of the NGO World Vision, former "white" president of the Association and previous director of Caucaia's Rural Workers Union, stated in an interview that the Tapeba issue was key to instigating agrarian reform in Caucaia.

The Rural Workers Union had previously been an important actor in the initial process of political organization and struggle for land. A decade before the church began to work through the EACR and the ACRC, the union mediated one of the main experiences for recognition of the Tabepas' rights to land - in the context of the progressive expropriation of their ancestral territory presented before. It involved a precarious concession of plots of land that gave origin to the Vila dos Tamancões, a nucleus of the Lagoa do Tapeba 1 village. Gilberto Rocha Miranda, having inherited part of the land of his father, Alfredo Miranda, coerced the Tapeba families who resided there to leave the land where they lived as "residents" for generations. Because they felt it was an injustice and judged that Gilberto did not have the right to "expel them without the right to anything", the chiefs of the displaced families turned to the union. In March 1976, the union was able to have declarations issued for each head of family, assuring permission to build houses and improvements on very small lots, promising them at a future date a deed for the transfer of rights to possession - which never took place.

Another accomplishment of the EACR was the production in 1985 of the documentary film Tapeba: resgate e memória de uma tribo ${ }^{12}$ [Tapeba: revival and memory of a tribe] and of the Survey of the Tapeba Indians, completed between March and September 1986, which found 914 people in 185 families living in the communities recognized at the time. Part of the responsibility for having the Tapeba leave the "swamp" - that is, the land within the mangrove swamp of the Ceará River - was also due to the work of the EACR, which had brick houses built for the Tapeba at Pontes. ${ }^{13}$

After countless transformations in their composition, definition of purpose and forms of engagement, the Association of Communities of the Ceará River became the Association of Communities of the Tapeba Indians of Caucaia (ACITA). Recognizing its genesis in that period, on Oct. 14, 2015, in a plenary session of the Ceará state legislative assembly, ACITA, with support from allied politicians , promoted a "solemn session in homage of the 30 years of our association, which marks the history of struggle of our people in support of the demarcation of our lands and the struggle for rights". They invited "all indigenous relatives, partners and supporters". It would have been unthinkable to promote a session like this in the mid-198os, in the political context of the military dictatorship, when the Tapebas' association was still incipient.

Another attempt to establish a principle of unification and a milestone of support for the mobilization was the declaration of October 3, the eve of Saint Francis Day, as the Day of the Tapeba. This is because on Oct. 3, 1984, the man considered the last indigenous chief, "Cabo" Vítor, a son-in-law of Perna-de-Pau, died of a heart attack. With this "date for a festival, a mass and a march of the communities to the cemetery",

\footnotetext{
12 The documentary is 40 minutes long and based on a study by sociologist José Cordeiro (who was then coordinator of the Rural Communities Assistance Staff). It was produced by Hoje - Assessoria em Educação [Educational Assistance] (in which Cordeiro also worked) with resources from the Dutch Embassy and from four other religious organizations, and directed by Eusélio Oliveira. The documentary was very important, at the time, to give visibility to the Tapeba, and is available on Youtube (https://www.youtube.com/watch?v=NxwxHx3 $\mathrm{T} 1 \mathrm{Gs}$ ).

13 When in Caucaia for the first time, in November 1986, I had the opportunity to register the precarious and temporary housing where the Tapeba lived for a long time "in the mud", "in the swamp".
} 
the EACR sought to strengthen "community" ties, thus giving shape to the Tapeba's sense of constituting a whole. The testimonies report that Victor's burial was a mobilizing event, involving family members from all the villages. A demonstration left Pontes village for the cemetery at the center of the municipality, where he was buried in a small plot of land donated by the owner of a funeral company. In 1986, Archbishop Dom Aloísio Cardeal Lorscheider held a mass on October 2 that mobilized the religious authorities of the municipality. During the service he presented a letter to the Tapeba and the Ceará communities that was widely distributed. This earned broad coverage in the local press with front page headlines. Since then, the Tapeba hold an annual march through the center of Caucaia on Oct. 3, together with other celebrations that they reworked (see next section).

This was also a period with many public demonstrations supported by segments of civil society. On July 19, 1987 the "Surpreendamental Parada Voadora a Caminho do Infinito" [The Astonishing Flying Parade on the Path to the Infinite] was held in Fortaleza. The march began at 4 pm, from the Circo Voador (The Flying Circus, a prominent cultural center at the time), passing along the Beira-MarAvenue, with 160 indigenous people, joined by various civil society entities that composed the Pro-Tapeba Committee. The march was set for this date because it marked the end of a 30 -day eviction notice issued in favor of a food corporation against five of the 64 families who lived in Vila Nova. On the previous morning, Dom Aloísio had visited some communities in the company of Cardinal Simonis, Bishop of Utrecht. On that same week, before the visit of the Cardinals, two representatives from the northeastern branch of the Indigenist Missionary Council (CIMI) were in the region, as well as the coordinator of the Union of Indigenous Nations (UNI) for the Brazilian Northeast, Apolônio Xokó. The three presented letters and declarations to the press about the situation of the Tapeba. The "Parade" ended with a show from the popular musician Fagner at the Circo Voador, and not only did it demoralize the legal eviction order issued for the TBA company (the specific focus of the demonstration), but decisively contributed to strengthening the performative discourse in the struggle to have the Tapeba acknowledged as an indigenous people.

Here we are in the domain of the "strategy of the demonstration" and of the "dialectics of the demonstration", which has a determinant place in the imposition of perceptions and categories of perception that are at play in struggles for identity (cf. Bourdieu 1989: 117-118). The visibility that the Tapeba attained locally, regionally and nationally, the strengthening of their political organization , and the relative recognition of citizenship that they achieved since the mid 1980s, and over more than three decades of struggle, have contributed to the recovery of their self-esteem as is expressed in the use of the term "recognition" in their statements. It is not that the Tapeba were not recognized in the sociological sense of the term, because, as Bourdieu observes (1989: 117), "identity [is] this perceived being that exists fundamentally by the recognition of others". They were, but in a stigmatized way by the regional population: "they did not have a name", "they were dogs", "they were not people" - as they themselves admit. When they spoke of "recognition", they expressed a change in the attribution of status that was imbued in ethnic ascription: they were no longer perceived as inhuman, and assumed protagonism as subjects with collective rights. The change from being stigmatized to the relative recognition of their citizenship as subjects with collective rights, affected their perception by regional society and their self-image.

On the part of regional society, in addition to the already mentioned demonstrations organized by the church and civil society organizations, we see this recognition formalized in various legal and administrative diplomas, since the mid-1980s. Some of these even highlighted the close link between the Tapebas and the ecosystems that they inhabited, particularly the mangrove of the Ceará River. The Secretariat of Administration and Finances of Caucaia had the opportunity to declare to the Serviço de Patrimônio da União [Federal Patrimony Service], on August 21, 1985, that the Tapebas had lived on the Ceará River for more than 50 years. On the next day, it sanctioned Municipal Law \# 416, of August 22, 
1985, declaring the mangrove swamps of the Ceará river basin as an area of environmental protection and authorizing the Tapeba to monitor and zeal for compliance with this law. ${ }^{14}$ In 1989, the state of Ceará, in an unprecedented manner, recognized in the state constitution, the rights, assistance to and the physical and cultural preservation of the Indians in its territory. ${ }^{15}$ The following year, Caucaia's Municipal Charter, approved by the city council, included respect for the indigenous peoples, as one of its "fundamental principles", thus reiterating the recognition of the Tapeba as a distinct indigenous people. ${ }^{16}$

On the part of the Tapebas, as regards the stigma, all of this led to reconsidering the permanently tense connection between continuity and change in relation to the elders, the old people, denoted by expressions such as "tronco velho" [old trunk], "raiz do pau" [root of the tree], "da gema" [from the yolk] and "ponta de rama" [tip of the branch] - which express their concepts of time and social organization. At times, the Tapeba use disparaging stereotypes to refer to themselves, even the most pejorative ones. By doing this, they reinforce the collective recognition that they are distinguished from the whites by some of this behavior, even because they "were torn from the old trunks". But if we thus have an assertion of continuity in relation to disreputable behavior - "sure I like to have a shot" - we also note an emphasis on the changes in relation to the customs of the most elderly - "they are now more tame". The tension between the "old trunks" and "the tips of the branch" must be understood in terms of their current recognition as citizens, who are subjects with rights, an experience that is radically distinct from that of the period in which "they lived cast aside", "had no name", "were dogs" and "were not people".

It is important to emphasize that all this took place in the historic, political and institutional context of democratic transition in Brazil. The mid 1980s was a period in which Funai was still used for implementing national security guidelines (under strong pressure from the military government), but also of intense mobilization by indigenous peoples and their partners for the recognition of their rights during the National Constituent Assembly. Indigenous associations and civil society organizations - which at the time were recently established - as well as progressive sectors of the church, linked to Liberation Theology, formed a quite active indigenist political field. This explains the already mentioned political influence of the Northeastern branches of CIMI and UNI, in Fortaleza and Caucaia, in 1987, in support of the Tapeba, alongside Dom Aloísio Cardeal Lorscheider, as well as the formation of the Pro-Tapeba Committee and the political action of religious and lay people who were engaged locally. ${ }^{17}$

In part, this also helps to understand the favorable attitudes of the state and municipal governments towards the Tapebas at the time. The effects of the enactment of the Federal Constitution of 1988 with a set of rights acknowledged in a chapter entitled "On the Indians", were echoed in the attitudes and resolutions taken by the state and municipality immediately after 1988. Finally, some of the favorable municipal government positions coincided with the first mandate of Mayor Domingos José Brasileiro Pontes, who

\footnotetext{
14 "Article 7. Sole paragraph - The participation of the citizen, of the Association of the Ceará River Communities, of the Tapeba Indians' Community and of preservationist entities in the monitoring that this legal measure calls for is guaranteed" (emphasis added).

15 "Article 287 - The state will respect and insure respect for the rights, material goods, beliefs, traditions and guarantees acknowledged to the Indians by the Constitution of the Republic $§ 1^{\circ}$. The Public Ministry will designate one of its members to provide permanent legal and court assistance to the Indians of the state, their communities and organizations, in the terms of article 232 of the Constitution of the Republic. $\$ 2$. The state will provide to the Indians of its territory, when solicited by their communities and organizations, and without interfering in their habits, beliefs and customs, technical assistance and means of survival and physical and cultural preservation".

16 "Article 10. The municipality of Caucaia [...] adopts, in the exercise of its autonomy and as a definition of its existence, the following fundamental principles: [...] III - Absolute respect for the indigenous peoples and/or their remnants with guarantee of support to the peoples, preservation of their cultures and recognition of their social values as part (and shapers) of municipal, state and national public patrimony, and identical recognition to the normal contribution of the black race; IV - the Municipality will provide to the Tapeba people who are fixed in its territory, if solicited by their communities or organizations, without interference in their habits, beliefs and customs, technical assistance and means for their survival and physical and cultural preservation" (emphasis added).

17 The importance of this conjuncture in the recent history of Brazil turned it into an object of a vast analytical literature in various fields of knowledge. It would be burdensome to refer to all of this literature, which focuses on the conformation of the broader political field and the indigenist field in particular. I will mention only a few titles that condense some of the important dimensions of the transformations experienced at the time, as expressed in their titles: "crisis of indigenism" (Cardoso de Oliveira 1988), "essays in indigenous citizenship" (Pacheco de Oliveira \& Freire 2006), "tutelage and participation", "indigenous peoples and forms of governance” (Souza Lima 2015) and some chapters from the collection by Pacheco de Oliveira (1999a).
} 
returned to govern Caucaia again from 2000 to 2004 (at the time of the second identification study for the demarcation of the Indigenous Land). Domingão, as he was known, was a popular, charismatic and folkloric political leader - known at times as the mayor who "drinks but works". He owned a medium-size firm in the export sector of carnaúba wax and cashew nuts (extractive activities in which many Tapebas worked), without real estate interests in the municipality.

\section{The demarcation of the Tapeba Indigenous Land, the policies of recognition and the "retakings"}

The political demonstrations aforementioned, and the official declarations and legal rules produced since 1985 by different actors, made possible various institutional linkages based on the recognition of the Tapeba as an indigenous people. Of these, the main one was that which led to the recognition of their territorial rights by means of the administrative procedure for the demarcation of the Tapeba Indigenous Land. Since its initiation in $1985,{ }^{18}$ this procedure was led in parallel to the recognition of the Tapeba by Brazilian society and the state - at its various levels (federal, state and municipal) - given the progressive accumulation of evidence in this direction. One can say that the Tapeba won the symbolic struggle for recognition, with very few now questioning their ancestry. ${ }^{19}$ If today they are political subjects in their own right, and are served by the policies of indigenous school education and differentiated indigenous healthcare, the struggle for demarcation of the indigenous land was the backbone of this entire process and continues until today.

The Tapeba Indigenous Land was the object of three identification studies. Since its first identification, in 1986, it passed through all the vicissitudes of the various changes in the administrative procedure for demarcation of indigenous lands, surviving all of them. During this period, the Indigenous Land changed in perimeter and area, although fundamental territorial elements have been conserved over time. Given the limits of this article, I will only refer to the most significant aspects.

Considering 1984 as a reference year, because it was when the EACR began its work in Caucaia, the official recognition of the Tapebas and their land by the federal government, at this first moment, was relatively agile. Everything took place in about four years at a time when Funai was not even present in Ceará. Funai included the Tapeba Indigenous Land in the operating program of the Identification Division in 1985; the first identification study was concluded in October 1986; the land survey was conducted in September 1987; and the process was reviewed by the Interministerial Working Group (GTI) created by Decree $\mathrm{n}^{\circ}$ 94.945/87 in July 1988. All of this took place before the enactment of the Federal Constitution of 1988. The GTI decided that the procedure be dropped for reasons that cannot be detailed here. This decision triggered a generalized reaction from the Tapebas, social movements, the Archdiocese, the state government, CIMI Northeast, the Federal Attorney General's Office and the state legislature of Ceará, as well as countless other civil society organizations, and the local press gave broad coverage to these responses.

\footnotetext{
18 When it was included in the operational program of Funai's Identification Division (DID). The original document of the Funai Process/BSB/1986/85 is a petition from 70 Tapebas, dated May 20, 1985, which was filed simultaneously in three different locations: the office of the Presidency of the Republic, the office of the Ministry of the Treasury and the office of the President of Funai. To the latter, the 70 Tapeba signatories requested "land for us to live on and plant" and "a medical clinic and school for the Indians". In April 1985, a month before this petition was submitted, another process began in another division of Funai: the Assessoria de Estudos e Pesquisas [The Study and Research Advisory Board] (AESP) - for reasons that cannot be explained here given the limits of this article.

19 The opponents and detractors of the Tapebas, however, did not disappear. They may not be as impetuous as they had been, but their presence cannot be underestimated, given the erratic and multifaceted nature of political situations. In November 2016, for example, I participated as a witness in a public instructional hearing, called by a federal judge of the Third Court of the Judicial Branch of Ceará, as part of a public civil suit filed by the federal public ministry against the federal government and Funai (Process \# 0005825-39.2013.4.05.8100). The hearing was held in the auditorium of that judicial branch, in Fortaleza. The lawyer for a number of non-Indian occupants of the Tapeba Indigenous Land, Dr. Djalro Dutra, was there and repeated the affirmation that the Tapebas are not Indians.
} 
The land survey done at the time of this first identification study was an extremely conflictive process marked by death threats to the Tapebas and members of the EACR. Rural property owners resisted inspections of their land. Many sold their properties, others subdivided them, and others undertook construction to strenghten their tenure claims. The change in the local rural landscape was noticed in the fencing of ponds, lakes and springs of common use for the Tapebas and regional residents; in the renewal and expansion of the fences; and in the progressive growth of subdivisions and leasing of lands - preferably to non-indigenous people.

After countless administrative and judicial procedures, some of which were related to regulatory changes - from the new constitution to new rules for the demarcation procedure - the Tapeba Indigenous Land was declared a permanent possession of the Indians by Edict \# 967, of 24/09/1997, of the Ministry of Justice, with an area of 4,658 ha. and a perimeter of $77 \mathrm{~km}$. The edict, however, was judicially challenged shortly afterwards by the municipal government of Caucaia (PMC) in the Superior Court of Justice (STJ) in suit \# 5.505/DF (97/0085188-5), filed on 11/19/1997. The municipal government alleged, among other things, that Funai had not complied with the decision of the Ministry of Justice, by failing to re-examine the limits of the area by including a representative of the municipality in the identification working group. In May 1998, the First Section of the Superior Court decided "to annul Edict \# 967/97 and all the acts practiced in the administrative process up to and including the publication, and [that] it proceed to the publication in the manner required by Decree \# 1.775/96".

The appeals from the Tapeba were rejected by the First Section of the STJ on Dec. 9, 1998. One year later, on Dec. 30, 1999, Marcelo Luís C. Rodopiano de Oliveira (OAB 5.294/DF) undersigned a communiqué of Funai's general attorney (Informação no 867), expressing his understanding (after reading the agreement and vote of the minister rapporteur of the suit), that Funai must establish a new working group, according to Decree \# 1.775/96. Only in January 2001 was the Tapeba Indigenous Land included once again on the list of lands for identification. Another year passed until Funai would determine, in Edict \# 1185/PRES/2002, the establishment of a working group to lead new studies of identification and delimitation of the Tapeba Indigenous Land, under the terms of Decree \# 1775/96 - a working group that I coordinated.

Note that after the unprecedented agility observed in the mid 1980s, the demarcation procedure of the Tapeba Indigenous Land entered the standard bureaucratic and political morass typical of the Brazilian state.

The summary of the Substantiated Report of Identification and Delimitation (RCID) of the second identification study was published in the Diário Oficial da União (DOU) on April 20, 2004, delimiting the Tapeba Indigenous Land with an area of $4,767 \mathrm{ha}$. and a perimeter of $81 \mathrm{~km}$. The procedure, however, was once again invalidated in court. The municipal government filed Complaint \# 2.651-DF alleging that the identification procedure of the Tapeba Indigenous Land had not respected the previous STJ decision in response to the suit the municipality had filed in November 1997, given that the second working group for identification did not include a representative of the municipality. The STJ ruled in favor of the municipality's complaint on June 11, 2008.

Note that until 2010, when the final ruling of the Superior Court was published, there was no law calling for the participation of states and municipalities in the demarcation of indigenous lands. It was only with Edict \# 2.498 of the Ministry of Justice of Oct. 31, 2011, that participation of the federative entities became mandatory in the administrative procedure for demarcation of Indigenous Lands. In a previous article (Barretto Fo 2017), I detailed all of these recent comings and goings of the demarcation procedure of the Tapeba Indigenous Land, and observed how it served as a trial balloon for heterodox innovations in this procedure. Some of the new requirements - such as the participation of representatives of states 
and municipalities and the realization of "dialog sessions" prior to administrative decisions - signaled the growing subordination of the demarcation of the indigenous lands to markedly political influence, making the recognition of territorial rights more vulnerable.

Schooled by the administrative and judicial manipulations, and wanting to assure greater knowledge and control over the demarcation procedure, the Tapebas matured in this process, always demanding greater participation in the identification studies. The creation of the first technical group for identification was preceded by an understanding between the institutions and organizations related to the issue, in order to keep Funai informed about the situation of the Tapebas and to demand the presence of an indigenous representative in the process. Thus, the working group established at the time included a representative of the EACR in its formal composition. It was not possible to have a formally recognized indigenous representative participate in the second working group for identification. Nevertheless, the Tapebas sent two of their most important leaders to accompany all the work. Still dissatisfied with the way information about the studies was disseminated at that time, in September 2010 the Tapebas formed a "Permanent Commission to Accompany and Integrate the Activities of the Working Group" to directly monitor the third study - in which the working group included participation of formally designated representatives of the municipality and the state. Comprised of 23 indigenous people representing the 11 main villages, the Commission traveled by van, monitoring the field work of the working group, which was undertaken in three different periods: September and December 2010, and May to June of 2011. In the two most recent studies - which I coordinated - we sought to fully comply with Decree 1.775/96 - that ascertains the participation of the indigenous group concerned, represented in its own ways, at all stages of the demarcation procedure.

The most recent Substantiated Report of Identification and Delimitation for the Tapeba Indigenous Land was completed in 2013, and was approved on May 23, 2013, through Technical Report \# 18/CGID/2013. The publication of its summary in the Diário Oficial da União (DOU), however, was delayed three months after approval, because of maneuvering that indicated the subordination of the procedure to political issues. These movements were strongly condemned by the indigenous movement, as I describe and analyze in Barretto Fo (2017). In parallel, in the judicial sphere, still in 2013, a new suit was filed in the Federal Regional Court (TRF) of the $5^{\text {th }}$ Region - this time by private groups - with the objective of annulling the Tapeba Indigenous Land demarcation procedure (Restraining Order (MC) \# 0801865-92.2013.4.05.00o). The estate of Emmanuel de Oliveira de Arruda Coelho alleged that he had been denied the right to challenge the administrative procedure during its due course and that his property, known as Soledade Farm, which partially coincides with the delimited indigenous land, had been economically exploited by his family since the early twentieth century. Although there is no legal requirement to notify private parties who hold land deeds within indigenous lands studied by Funai and although the proponent of the suit had already filed administrative questionings in different steps of the demarcation procedure, the argument was accepted and the process suspended once again.

Instead of appealing the decision, Funai - based on what it considered to be the Tapeba people's right to exercise their free, informed and sovereign will, although acknowledging that part of the group was in a situation of vulnerability - articulated with them a judicial agreement to overcome this impasse. Celebrated between the Tapebas, representatives of the Arruda family, the state and municipal governments, Funai and the Ministry of Justice, the settlement agreement was judicially approved on April 19, 2016 and called for the removal of areas from the Tapeba Indigenous Land, as it had been demarcated in August 2013 with an area of $5,838 \mathrm{ha}$. and a perimeter of $100 \mathrm{~km}$ for an estimated population of 6,559 inhabitants. It thus excluded a part of the Soledade Farm owned by the Arruda family and two other areas of interest to the municipal government of Caucaia. In compensation, two other parts of the Soledad farm remained within 
the delimited indigenous land, one of which went beyond its limits, but which would be incorporated to it under the terms of the agreement. The Arruda family dropped its suit to annul the demarcation process of the indigenous land. The other participants in the agreement, within their attributions, undertook to implement a set of actions with clear deadlines.

The main action was the issuing of the declaratory Edict by the Ministry of Justice, which took place on Sept. 4, 2017, through Edict \# 734, of August 31, 2017, which declared the Tapeba Indigenous Land to be a permanent possession of the indigenous people, with an area of 5.294 ha. - therefore, smaller than the area demarcated in August 2013.

Presented in this manner, it appears that the entire procedure took place at a merely administrative level, when in fact, the Tapebas were protagonists of struggles, conquests and resistance that have kept the process alive until today. Two elements central to the mobilization of the Tapeba that drove the recognition of their territorial rights were the struggle for differentiated indigenous school education and the actions to retake portions of their territory - which in turn, are related to the strong demographic expansion that they experienced in the past 20 years.

There is a close connection between the processes of reconquering land, which intensified since the late 199os, and the indigenous schools. Nine of the eleven indigenous schools existing in the Tapeba Indigenous Land in 2012 were in peri-urban and rural zones - an indicator of the importance of the indigenous presence in these zones - and all of them in areas retaken by the Tapebas (Nascimento 200gb: 146; Tófoli 2010). Schools are central to Tapeba culture, identity and politics and this is evident in their struggle to expand the provision of education, as well as its qualification and investments and improvements in public facilities. Between 2001 - when the process of differentiated indigenous teacher training began - and 2004 - when the first class graduated from this course - the number of indigenous schools rose from three to nine, with a sharp rise in the number of teachers and students (Tófoli 2010: 66). In 2012, nearly $25 \%$ of the Tapeba indigenous population was matriculated at some level of schooling. From a situation where schools functioned with precarious infrastructure and indigenous teachers worked voluntarily, without specific teaching materials, most often outdoors or in precarious buildings (see photos in Nascimento 2009b: 141144), schools became a target of investments by the state government in the construction of new facilities.

This is also reflected in the pedagogical practices of the indigenous Tapeba teachers, which, as Nascimento observed, constitute "a form of ritualization of ethnic resistance". The types of "responses and ways of coping with situations of prejudice", thus contributed to consolidating "the image of the differentiated school as 'the place of culture"' (Nascimento 2009a: 112 and 157). An expression of this is the connection of the celebration of Tapeba Indian Day (each October 3), with the "Carnaúba Festival", the "Indigenous Games" and the "Indigenous Cultural Fair". This fair is promoted yearly in October by teachers and students of the indigenous schools, by the Tapeba Indigenous Teachers Association (APROINT) with support from ACITA, Funai, the state secretariat of education, the Education Council of Ceará and the municipal secretariats of education and culture of Caucaia. The Indigenous Culture Fair lasts for three days, during which there are exhibitions of products, presentations by students and, on the last night, the "Carnaúba Festival". This festival is usually held in October, between Saint Francis day and Brazil's Patron Saint day, October 12, in the sacred yard of the paus-brancos (white woods), to the south of the Tapeba lake, to celebrate the value of the carnaubeira (Copernicia prunifera) and its derivatives in the Tapeba economy. ${ }^{20}$

Meanwhile, although in a broad sense land retakings are not a novelty among the Tapebas, they did

20 It is not by chance that the Tapeba call it the "tree of life". This is the title of an 18-minute documentary film they produced themselves during the "Workshops in Education, Reporting and Creating in Community Journalism" (specifically the workshop in Indigenous environmental cinema) of the Program in Social Communication with the Tapeba and Anancé Communities of the "Basic Environmental Plan (PBA) - Tapeba and Anacé Indigenous Component" of the Project to Increase the Capacity and Improve the BR-222/CE federal highway. The documentary can be seen at http://www.youtube.com/ watch?v=dbRFkkIvzXc 
intensify in the late 1990s (see table with general data in Tófoli 2010: 148) in a synergic relationship with the demarcation of the Tapeba Indigenous Land. We recall that the first declaratory edict of the Indigenous Land was in 1997. Tófoli (2010) - who was an assistant to the working group that ledthe third identification study - historically and ethnographically describes, and presents georeferenced data for 16 retakings of land related to ten Tapeba local groups over nearly 20 years. She alludes to the motivations and presents the uses of the spaces thus appropriated in each retaking, while comparing them to the result of the identification studies of the Tapeba Indigenous Land. In doing so, Tófoli defines the retakings as "geographically referenced political actions that impact [the] sociability of individuals". They emerged "mainly due to the decrease in spaces available in the territory that they traditionally used, and to the historic relationship of domination of the local farmers over the indigenous population, which constantly forced them to change their residence". To this was added, since the second half of the twentieth century, the "dynamic of occupation of spaces imposed by the logic of capital, perceived in the construction and expansion of highways that cut through the territory, the growing urbanization and industrialization, which accentuated the strangulation of the accessible spaces" (Tófoli 2010: 88-9).

Tófoli's study reveals the close connection of the land retaking processes with the provision of space for housing and schools. It also addresses the importance of access to resources needed for social reproduction and economic and cultural well-being (water and land for cultivation) which complement the also important aspect of sociability and social interaction (football). The issues are closely related to the installation of public facilities: the schools themselves, football fields, health clinics and cultural centers. These are ways to consolidate the occupation of these areas and efforts to overcome the persistent instability and the mood of permanent threat of eviction that weigh on the Tapeba settlements until today. It is thus not surprising that nearly all of these land retakings have involved conflicts with occupants and the police.

The land retakings therefore represent both an authentic anthropogeographic movement and an autonomous political movement. They are anthropogeographic because the Tapebas, on one hand, are experiencing accentuated demographic growth that the insignificant parcels of land where they live today are not able to sustain. On the other hand, the Tapeba attempt to adapt their geographic volume - the areas that they effectively occupy and through which they move daily - to their mental volume - the territory recognized as theirs through their oral traditions. The issues are political because they involve performative acts by which the Tapebas attempt to express, through effective actions, their demands and the understanding that they have of the situation in which they live today. Even if they do not directly and intentionally question the procedures for demarcation of the Indigenous Land, the retakings interact with them by reckoning the significance of the opportunities created and by expressing the Tapeba anthropogeography.

\section{Final considerations}

A toponym, a referent of common ancestry and an allusion to a specific way of being, Tapeba has been configured as an ethnic subject and territory during a long historic process in which a varied and changing set of agents and institutions have interacted. Fruits of hybridization and individuation of segments of distinct indigenous peoples submitted to mutant regimes of administration of indigenous peoples and corresponding laws for ordering land ownership, they have emerged and constituted themselves as a group and a territory by means of various forms of accommodation and resistance to mechanisms of control, domination and discipline that have sought to repress, annihilate or assimilate them.

Contemporarily, their political-identity project has focused on the conquest of demarcation of their land, whether through political engagement in the administrative sphere, or through retakings of land; 
and in securing access to formal education, in which the differentiated school is seen as an important place of culture. The Tapeba demographic expansion of the past 20 years should be understood within the framework of the feedback effects on the ethnic dynamic of public policies of differentiated attention and access to indigenous healthcare and education. These policies have been established and consolidated since the mid 199os, and have favored the Tapeba, even if precariously. Because of the positive discrimination prompted by these policies, many Tapeba are no longer ashamed of their condition as Indians. Overcoming the stigma that still weighs against them, they came to recognize themselves as indigenous. Moreover, there has been an expansion of literacy among the Tapeba, sparked by differentiated and intercultural education (and all that goes along with this), an improvement of their sanitary conditions and an expansion of their coverage by vaccines.

It is not necessary to think far ahead to calculate the consequences of these processes - whether in terms of recovery of self-esteem, or in terms of the (re)valuation of the history and ancestry of the group - for the demographic dynamics and the ethnic frontier. The Tapeba today live in permanent and intense contact with the regional population: they are engaged in local productive activities; there are interethnic marriages, which are more frequent in certain local groups than in others; they maintain relations of social proximity, through the constitution of fictitious kinship relations; and in certain cases maintain a relative cordiality in neighborly relations. The growing awareness of their rights as an indigenous people and the effects of the policies they have pursued over the past two decades mean that the estimate of the Tapeba demography is not completed and the generous identity mesh that binds the group together is open ended - which helps us understand the enduring expansion of their vital space.

Received: October 16, 2017

Approved: March 12, 2018

Translated by: Jeffrey Hoff 


\section{References}

AHMED, Akbar. 1984. "Hazawaral: formation and structure of district ethnicity in Pakistan". In: D. Maybury-Lewis and S. Plattner (eds.), The prospects for plural societies. Washington: American Ethnological Society. pp. 104-120.

ALMEIDA, Geraldo Gustavo de. 1988. "Perna de pau”. In: Heróis indígenas do Brasil: memórias sinceras de uma raça. Rio de Janeiro: Cátedra. pp. 103.

ALMEIDA, Rita Heloísa de. 1986. Relatório de viagem ao município de Caucaia, Ceará. Brasília:

Coordenadoria de Terras Indígenas-CTI/MIRAD. Mimeo.

BARBOSA, Wallace de Deus. 2001. Um embate de culturas: análise de processos políticos e estratégias socioculturais na construção das identidades Kambiwá e Pipipã. Tese (Doutorado em Antropologia Social) - UFRJ. 278 p.

BARRETTO Fo, Henyo. 1993a. Tapebas, tapebanos e pernas de pau: etnogênese como processo social e luta simbólica. Dissertação (Mestrado em Antropologia Social) - PPGAS/MN/UFRJ. Rio de Janeiro. 692p. . 1993b. "Tapeba”. In: J. Pacheco de Oliveira and J. C. F. Leite (orgs.), Atlas das terras indígenas do Nordeste. Rio de Janeiro: PETI/Museu Nacional/UFRJ. pp. 48-50. . 1999. "Invenção ou renascimento? Gênese de uma sociedade indígena contemporânea no Nordeste”. In: J. Pacheco de Oliveira (org.), A viagem da volta: etnicidade, política e reelaboração cultural no Nordeste indígena. Rio de Janeiro: Contracapa. pp. 91-136. . 2000. "Identidades emergentes, soluções heterodoxas: o caso da (não) demarcação da Terra Indígena

Tapeba”. In: FUNAI (org.), Política indigenista no Nordeste e Leste. Brasília: FUNAI/DEDOC. pp. 27-39. . 2005. Relatório circunstanciado de identificação e delimitação da TI Tapeba. Brasília, DF: Funai. Mimeo. . 2013. Relatório circunstanciado de identificação e delimitação da TI Tapeba. Brasília, DF: Funai. Mimeo. 2017. “'Protagonismo' como vulnerabilização em demarcação de Terras Indígenas: o caso do acordo judicial para demarcar a terra Tapeba". Revista Brasileira de História, 37(75): 217-240.

BEOZZO, Oscar. 1983. Leis e regimentos das Missões: política indigenista no Brasil. São Paulo: Loyola. BOURDIEU, Pierre. 1989. O poder simbólico. Lisboa: DIFEL/ Rio de Janeiro: Bertrand Brasil.

BRAGA, Renato. 1967. "Caucaia”. In: Dicionário geográfico e histórico do Ceará. Volume B-C. Fortaleza: Imprensa Universitária do Ceará. pp. 341-353.

BRIGIDO, João. 1879. Ceará: homens e fatos. Rio de Janeiro: Typ. Besnard Frères.

CARDOSO DE OLIVEIRA, Roberto. 1988. A crise do indigenismo. Campinas: EdUnicamp.

CARVALHO, Maria Rosário Gonçalves de. 2009. “O Monte Pascoal, os índios Pataxó e a luta pelo reconhecimento étnico”. Caderno CRH (UFBA. Impresso), 1: 507-521.

COMAROFF, Jean; COMAROFF, John. 2010 [1992]. "Etnografia e imaginação histórica". Proa - Revista de Antropologia e Arte [on-line], ano 02, 1(2): 1-72. Disponível em https://www.ifch.unicamp.br/ojs/index. php/proa/article/download/2360/1762. Consulted on 26/01/2018.

CORDEIRO, José. 1989. Os índios no Siará: massacre e resistência. Fortaleza: Hoje/ Assessoria em Educação. CUNHA, Manuela Carneiro da. 1992. "Política indigenista no século XIX”. In: M. M. Carneiro da Cunha (org.), História dos índios no Brasil. São Paulo: Cia. das Letras/FAPESP/Secretaria Municipal de Cultura. pp. 133-154.

DANTAS, Beatriz G.; SAMPAIO, J. A. L.; CARVALHO, M. R. 1992. "Os povos indígenas no Nordeste brasileiro: um esboço histórico”. In: M. M. Carneiro da Cunha (org.), História dos índios no Brasil. São Paulo: Cia. das Letras/FAPESP/Secretaria Municipal de Cultura. pp. 431-456.

DATAS de Sesmarias. 1925. Volume 6 (361-500). Fortaleza: Typ. Gadelha.

FAULHABER, Priscilla. 1989. "Terra devastada: agricultura e extrativismo no 'fim do Brasil”". Trabalho apresentado no Encontro Nacional dos Grupos Temáticos do PIPSA. Belém, PA, de 13 a 
16 de junho. Mimeo.

FIALHO, Vânia. 1998. As fronteiras do ser Xukuru. Recife: Massangana.

GOMES, Jussara Vieira. 1985a. Breve informação sobre os índios do município de Caucaia, estado do Ceará. Rio de Janeiro: CENDOC-Museu do Índio/FUNAI. Mimeo.

. 1985b. Relatório sobre os índios do município de Caucaia, estado do Ceará. Rio de Janeiro: CENDOC-

Museu do Índio/FUNAI. Mimeo.

GRÜNEWALD, Rodrigo de Azeredo. 2004. "Etnogênese e regime de índio na Serra do Umã". In: J.

Pacheco de Oliveira (ed.), A viagem da volta: etnicidade, política e reelaboração cultural no Nordeste indígena. Rio de Janeiro: Contra Capa. pp. 139-174.

IBGE. 1959. "Caucaia”. In: Enciclopédia dos municípios brasileiros, v. 4. Rio de Janeiro: FIBGE. pp. 150-158.

LEITE, Serafim. 1943. História da Companhia de Jesus no Brasil. Vol. 3. Rio de Janeiro: Imprensa Nacional. MACHADO, José de A. 1902 [1805/06]. "Notícia das Freguezias do Ceará visitadas pelo Pe. José de

Almeida Machado nos annos de 1805 e 1806, extrahida d'um livro de Devassas qu serviu na Visita".

Revista do Instituto do Ceará, Anno 16. Fortaleza. pp. 191-205.

MENEZES, Luis Barba Alardo de. 1871. "Memória sobre a Capitania do Ceará (1814)". Revista do Instituto

Histórico e Geográfico do Brasil, 34: 255-286.

NASCIMENTO, Rita Gomes do. 2009a. Rituais de resistência: experiências pedagógicas Tapeba. Tese

(Doutorado em Educação) - Programa de Pós-Graduação em Educação, UFRN, Natal. 208 p. . 2009b. "Rituais de resistência: performances e experiências nas práticas pedagógicas". In: M. A. da

S. Aguiar (ed.), Educação e diversidade: monografias. Recife: Gráfica J. Luiz Vasconcelos Ed. pp. 111-180.

PACHECO DE OLIVEIRA, João Pacheco de. 1999a. Ensaios em antropologia histórica. Rio de Janeiro:

Editora UFRJ.

. 1999b. "Uma etnologia dos 'índios misturados'? Situação colonial, territorialização e fluxos

culturais". In: J. Pacheco de Oliveira (ed.), A viagem da volta: etnicidade, política e reelaboração cultural no Nordeste indígena. Rio de Janeiro: Contra Capa. pp. 13-42.

. 2013. "Etnografia enquanto compartilhamento e comunicação: desafios atuais às representações coloniais da antropologia”. In: B. Feldman-Bianco (org.), Desafios da antropologia brasileira. Brasília:

ABA. pp.47-74.

.; FREIRE, Carlos Augusto. 2006. "Parte 4 - Ensaios de cidadania indígena [1988-2006]". In: A

presença indígena na formação do Brasil. Brasília: Secadi/MEC; Rio de Janeiro: Laced/Museu Nacional

(Série 'Via dos Saberes'; Coleção 'Educação para Todos'). pp. 186-204.

PAULET, Antonio J. Silva. 1898 [1816]. "Descripção geografica abreviada da capitania do Ceará pelo

Coronel de Engenheiros Antonio Jozé da Silva Paulet”. Revista do Instituto do Ceará, Anno 12.

Fortaleza. pp. 5-33.

PORTO ALEGRE, Maria Sylvia. 1992a. Fontes inéditas para a história indígena no Ceará. Fortaleza: UFC/ NEPS. . 1992b. "Aldeias indígenas e povoamento do Nordeste no final do século XVIII: aspectos

demográficos da 'cultura de contato"'. Trabalho Apresentado ao GT História Indígena e do

Indigenismo, XVI Encontro Anual da ANPOCS. Mimeo.

SAHLINS, Marshall. 1993. "Goodbye to Tristes Tropes: ethnography in the context of modern world history". Journal of Modern History, 65(1): 1-25.

SOUZA, Eusébio de (org.). 1933. Índice geral alfabético e remissivo das datas de Sesmarias do Estado do Ceará. vols. 1 a 14. Fortaleza: Officinas Gráficas da Cadeia Pública.

SOUZA LIMA, Antonio Carlos de. 2015. "Sobre tutela e participação: povos indígenas e formas de

governo no Brasil, Séculos XX/XXI”. Mana (UFRJ. Impresso), 21: 425-457.

STUDART, Guilherme (Barão de). 1896. Datas e Factos para a História do Ceará. Fortaleza: Typ. Studart. 
STUDART Fo, Carlos. 1963. “Os aborígenes do Ceará - II”. Revista do Instituto do Ceará (Fortaleza), 77: 153- 217.

TASSINARI, Antonella Maria. 1999. "Os povos indígenas do Oiapoque: produção de diferenças em contexto interétnico e de políticas públicas". Antropologia em Primeira Mão, 39: 1-37.

TÓFOLI, Ana Lúcia Farah de. 2010. As retomadas de terras na dinâmica territorial do Povo Indígena Tapeba: mobilização étnica e apropriação espacial. Dissertação (Mestrado em Sociologia) - PPGS/UFCE. Fortaleza, CE.

Henyo T. Barretto Filho

Department of Anthropology/University of Brasília

Contact: henyo@unb.br 